\title{
Malay Culture Effect on Career Planning Student SMA City 9 Bengkulu
}

\author{
Heni Sulusyawati \\ Universitas Hazairin (Unihaz) Bengkulu \\ Henisulusyawati9@gmail.com \\ Juwanto \\ Universitas Hazairin (Unihaz) Bengkulu \\ mrjuanto1510@gmail.com
}

\begin{abstract}
This research is motivated by the discovery of Malay culture students who have not thought of a clear career plan after graduating from high school, Malay culture students are also found to be confused in choosing majors in Higher Education. The purpose of this study was to determine the effect of Malay culture on student career planning. This type of research is a qualitative descriptive study with a natural setting approach. Data collection in this study using observation techniques, interviews, carried out simultaneously with data analysis. Data analysis using the Spradley model, namely through 4 stages of data analysis including domain analysis, taxonomic analysis, componential analysis, and discovering cultural themes. Based on the results of data analysis, it can be explained the influence of Malay culture on student career planning, namely: 1) discipline; students culture Malay discipline in completing the tasks of the teacher, 2) responsibilities; Malay cultural students have a high sense of responsibility in doing assignments, 3) light-handed; Malay cultural students have a mild attitude in mobilizing things that support learning activities, 4) high learning desires; Malay cultural students have a high desire in learning activities both at school and at home, 5) diligent; Malay cultural students are also classified as students who are diligent, it shows students in working on creative tasks.
\end{abstract}

Keywords: Malay Culture; Career Planning; SMA City 9 Bengkulu 


\section{Preliminary}

In the Industrial Era 4.0, each element has an important role, one of which is the element of education. Education has challenges in the formation of student character, so students will be ready to compete and can develop their careers according to their potential. Currently there are still students who drop out of school, even students do not have a mature career planning. In addition, students still do not know whether they want to continue their higher education or enter the workforce. 1 that student career planning is relatively high, but there are still indicators of career planning that are classified as moderate. Furthermore 2 showed that the tendency of students to group based on cultural background, career planning of students in the culture of serawai was classified as good, but in the indicators there were still classified as low, 3 shows that many factors affect student career planning, one of which is external factors, such as the condition of the school environment. In line with that, 4 explained that there are three main factors in career planning such as a) self-understanding; include intellectual abilities, talents, interests, strengths and weaknesses, b) knowledge of the world of work; includes the terms of a job, conditions that support the success of the job, the advantages and disadvantages of a job, and c) matching oneself with knowledge of the world of work, including short-term goals, longterm goals, and action plans. 5

Suggested that consideration of the importance of career planning for students in high school, such as the number of students completing formal education, emphasizes more comprehensive career planning guidance, career guidance is expected to include study development, job search techniques, skills as well as insight, decisions taken related to career placement in accordance with secondary school, in this case students are faced with internal and external pressure in making decisions, the main combinations after high school are quite clear in entering college, post-secondary school education, working or not working , military or government employee. Based on the previous explanation, it can be concluded that career planning for students is very important to plan

${ }^{1}$ Sulusyawati, H., Yusuf, A. M., \& Daharnis. (2017) Perencanaan Karier Siswa Di SMA Ditinjau dari Status Sosial Ekonomi, Jenis Kelamin, dan Jurusan. Jurnal Bikotetik. Vol. 01, No.01, pp.(0-36).

2 Sulusyawati, H., \& Juwanto. 2018. Potret Budaya melayu dalam Perencanaan Karier Siswa di SMA Negeri 9 Kota Bengkulu. Jurnal Psikodidaktika. Vol. 3., No., 2, pp. (1-49)

3 Aminnurrohim, A. W., Saraswati, S., \& Kurniawan, K. 2014. Survei Faktor-faktor Penghambat Perencanaan Karier. Indonesian Journal Guidance and Counseling: Theory and Application. Vol. 3, No.2.

${ }_{4}^{4}$ Duane, B., \& Associates. 2002. Career Choices and Development. Jossey-Bass business \& Management Series.

${ }_{5}^{5}$ Heer, E. L., Cramer, S. H., \& Niles, S. G. 2004. Career Guidance and Counseling Trough the Life Span: Sistematic approaches. Boston: Allyn and Bacon. 
early.6 Shows that career planning for students in high school is already high, but it is still found that there are still low career planning indicators.7

Explains that the students' career development process is divided into 5 stages namely: a) growth; ranged from birth until before the age of 15 years, at this stage of growth individuals develop various potential unique views, attitudes and interests of individuals, b) exploration from the age of 15 years to 25 years, this phase individuals begin to think about alternative positions, but have not been able to make decisions , c) this phase starts from the age of 25 years to 45 years, in this phase individuals begin to establish themselves through various experiences, d) management starts from the age of 45-65 years at this phase individuals can adjust and begin to appreciate the position, e. ) the release of the individual is at the age of 65 years and over, at this phase the individual begins to retire. Through this research, researchers will describe data about the influence of Malay culture on student career planning. The results of this study are expected to assist students in planning their careers going forward, of course, through the role of the Guidance and Counseling Teacher at school.

This research is a qualitative descriptive study using the Natural Setting approach, which better understands the phenomena experienced by research subjects. The informants in this study were students of Malay culture taken by purposive sampling technique. The research data collection uses participatory observation techniques, unstructured interviews, and documentation.8 Data analysis using the Spradley model that uses four stages of data analysis including domain analysis, taxonomic analysis, componential analysis, and discovering cultural theme.9

\begin{tabular}{|l|l|l|}
\hline $\begin{array}{l}\text { RESULTS AND } \\
\text { DISCUSSION }\end{array}$ & Phase Analysis & $\begin{array}{l}\text { Data Analysis Results } \\
\text { Malay culture Students tend to group with } \\
\text { friends sebayahnya, but did } \\
\text { hot mingle with friends rejang cultural } \\
\text { backgrounds and Serawai, } \\
\text { because students find it difficult Malay } \\
\text { culture while communicating. } \\
\text { That trend makes students less acceptable } \\
\text { Malay culture with friends. }\end{array}$ \\
\hline 2. & Analysis & $\begin{array}{l}\text { Based on the previous analysis of domain } \\
\text { analysis, it can be explained }\end{array}$ \\
\hline
\end{tabular}

${ }^{6}$ Sulusyawati, H., Hardianti, Susi. (2017) Perencanaan Karier Siswa dalam mengahadapi Masyarakat Ekonomi Asean (MEA).

${ }^{7}$ Sharf, R.S. 2010. Applying Career Development Theory to Counseling. Edition 5 TH Pacific Grove , California. University of Delaware: Brooks/Cole Cengage Learning.

${ }^{8}$ Sugiyono. 2012. Metode Penelitian Kombinasi: Mixed Methods. Bandung: Alfabeta.

${ }^{9}$ Sugiyono. 2018. Metode Penelitian Kualitatif dan R\&D. Bandung. Alfabeta. 


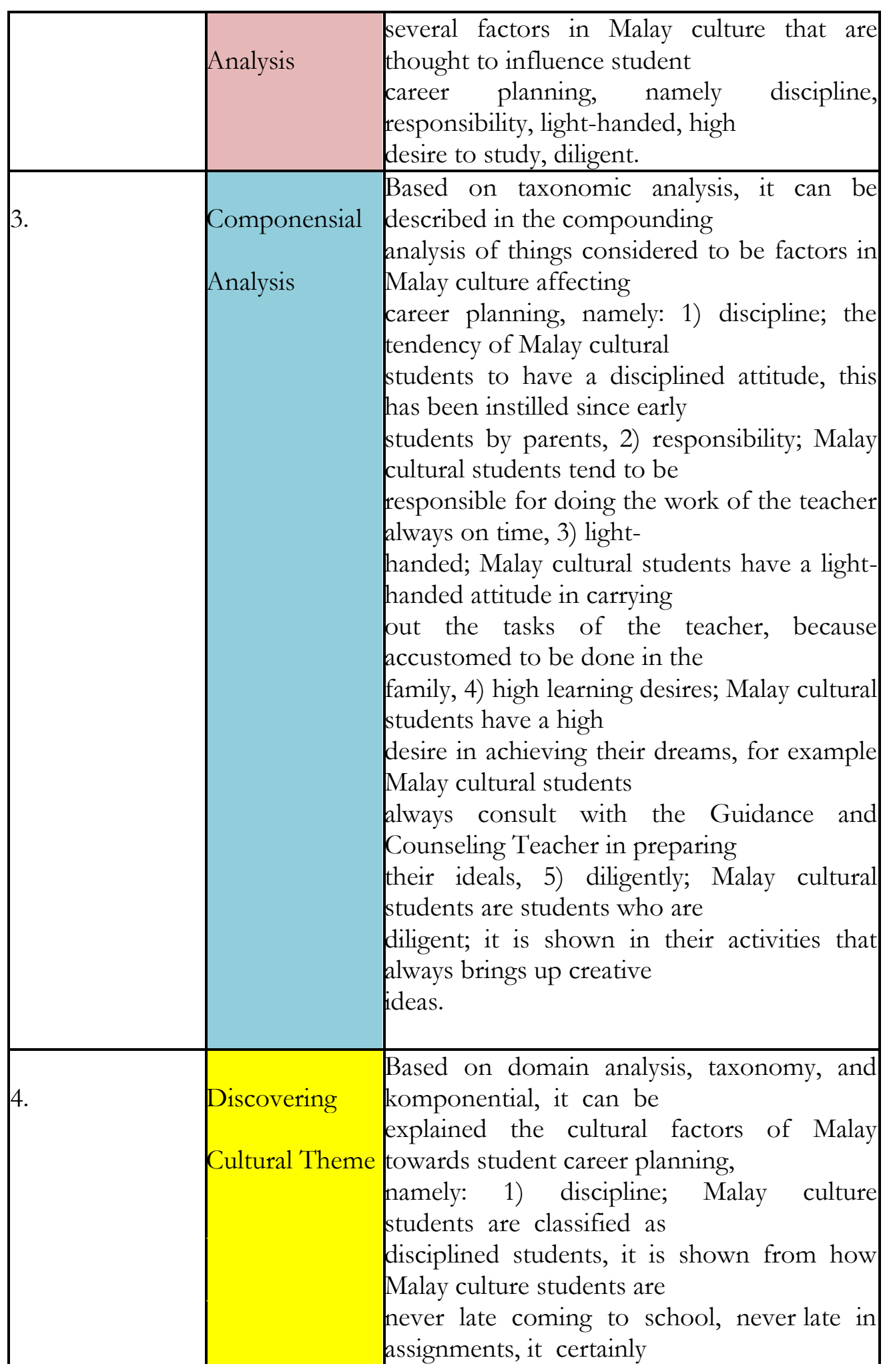




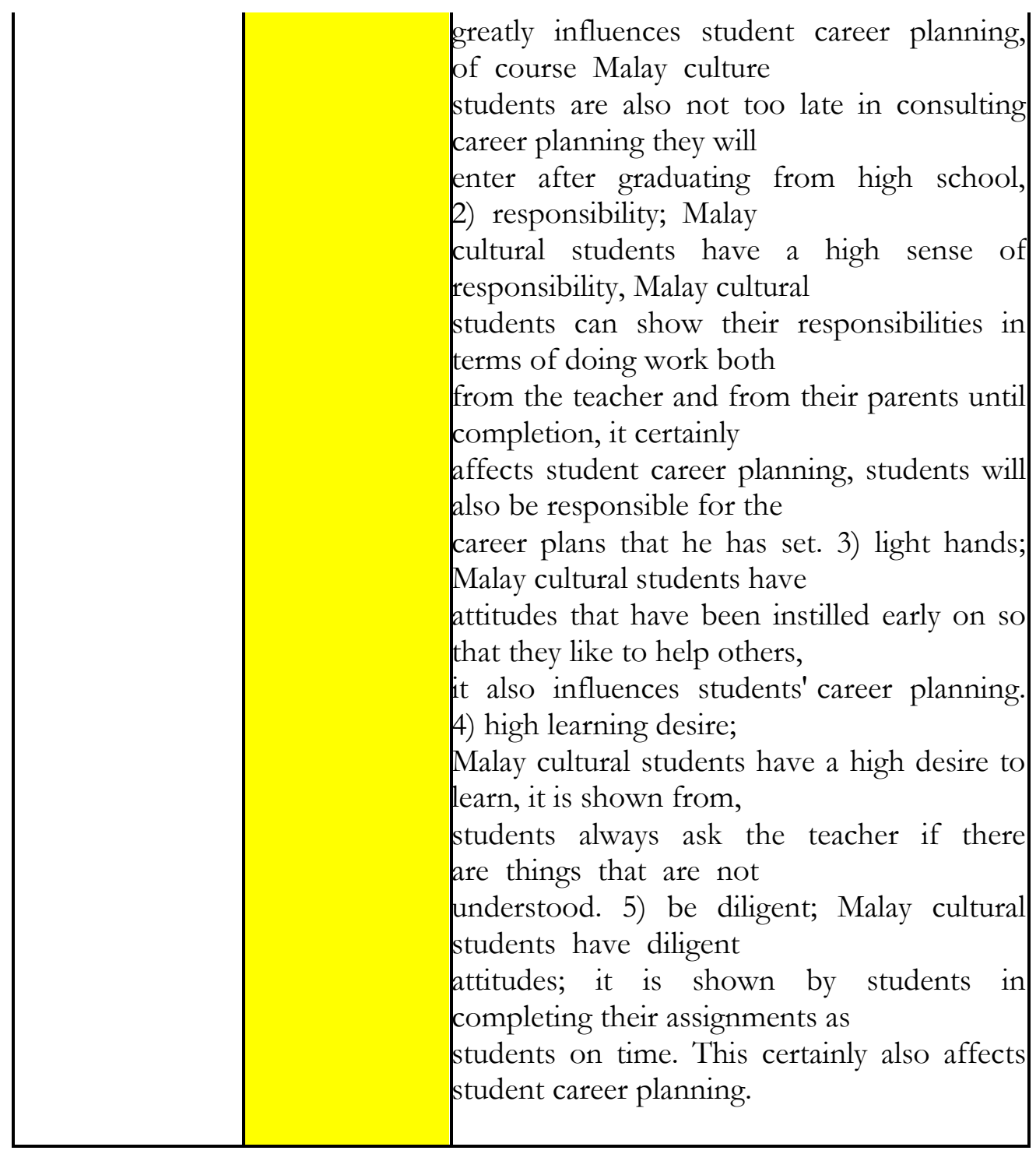

\section{Discipline}

Malay cultural students classified as disciplined students, disciplined behavior has been instilled by parents early on to children. Discipline is one of the behavioral habits in Malay culture that affects student career planning, because if students are disciplined students will not be late in preparing the desired career plan, of course career plans that are in accordance with the potential possessed by students. For example students will consult their career plans early to their parents and guidance and counseling teachers at school. After high school students do not feel confused in the next career plan. Whether entering college or entering the workforce. Of course, the tertiary 
institution chosen is in accordance with its competencies.10 Suggested that adolescence is seen as a critical time during which students must make important career decisions as orientation for career choices, career exploration and self-assessment, and commitment to career choices.

\section{Responsibility}

Malay cultural students have an attitude of responsibility, this attitude of responsibility is instilled early on by parents with children, especially for boys. The reason parents are because boys will be the head of the household, but that does not mean not for girls. Girls are also equally taught to be responsible for the tasks given by parents at home. This attitude of responsibility greatly influences students' career planning. Because in deciding the career plan desired by students not parents, not teachers, not relatives, not friends but students themselves. Of course, in making decisions is based on consideration and is ready to take responsibility for every decision taken. Usually if students are responsible, they certainly can develop their careers optimally.11 Shows that a person's gender aspect as a cultural variable influences desired career decision making.

\section{Helpful}

Malay cultural students also have a light-handed attitude, according to the Malay light-handed culture "doing everything without being told" in the culture of Malay children have been taught since childhood to have a lighthanded attitude, according to parents light-handed something that greatly shapes the character of the child in socializing, so children have been taught to be sensitive to the environment, especially family, school and community environments. For example, in an activity in school, students who are lighthanded will carry out their tasks without always being instructed, without thinking about the rewards. This light attitude can also affect student career planning. In terms of preparing for future career plans, if students are always waiting for new commanders to want to work, then students will be very difficult to develop a career in the future. In addition, if students only wait for instructions when they are independent. If students without being asked to do anything, it certainly is very related to the career plan they will choose. Because before students are asked to plan a career, students have done it without being told. Of course, the information obtained will greatly support the development

${ }^{10}$ Germeijs, V., \& Verschueren, K. (2006). High school students' career decision-making process: Development and validation of the study of one choice task inventory.Journal of Career Assessment,14, 449-471. doi:10.1177/1069072706286510.

11 Correll, S. J. 2002. Gender and the Career Choice Process: The Role of Biased SelfAssessments, American Journal of Sociology, 106, 691-730. 
and maturity of the chosen career.12 Suggests that racial and ethnic minority students have lower confidence to overcome obstacles than white students.

\section{High Learning Desire}

Malay cultural students, have a high desire to learn, when compared with other cultural students, who are behind the high desire to learn from previous pepata. As for the saying, "Rice as a Fish with a Mader Simplified Fish", according to students, the Malay culture of pepata applies to the past, not for now. Therefore parents of students always encourage and motivate their children to become successful children. Based on motivation and desire to progress, the high desire to learn, the desire to learn is one of the factors in Malay culture that can affect student career planning, because desire is one of the variables in student career planning. If students do not have the desire to learn, of course students will be difficult to achieve success in a dream career. Conversely, if students have a high desire to learn, students will certainly have a lot of knowledge related to the career plan they will choose. Of course Malay cultural students after graduating from high school have a careful career planning.13 Show that culture operates significantly influences student career choices. Furthermore, 14 Shows that the way students learn is influenced by their cultural background.

\section{Diligent}

Malay cultural students are students who are diligent, diligent in the context of Malay culture, that is, diligent in completing the assignments given by parents, or from teachers without being asked / ordered. The attitude held by Malay cultural students also influences student career planning, because achieving career success certainly begins with careful career planning by students from an early age. The diligent attitude held by Malay cultural students is related to how students complete their developmental tasks, namely preparing a mature career plan after graduating high school. If students do not have a diligent attitude of course also affects the career plan that students will choose later. So from this it is clear that diligence is one of the factors in Malay culture that affects student career planning. Showed that Malay culture students' career planning is classified as good, meaning that students have been able to understand themselves, know information about the world of work, and

12 Watson, M. B., Stead, G. B., \& De Jager, A. C. 2005. The Career Development of Black and White South African University Students. Interbational Journal for the Advancement of Counseling 18, 39-47

${ }_{13}$ Luzzo, D., \& Mc Whirter, E. 2010. Sex and ethnic differences in the perception of educational and carrer-related barriers and levels of coping efficacy. Journal of Counseling and Development, 79, 61-67.

14 Sulusyawati, H., \& Juwanto. 2018. Potret Budaya melayu dalam Perencanaan Karier Siswa di SMA Negeri 9 Kota Bengkulu. Jurnal Psikodidaktika. Vol. 3., No., 2, pp. (1-49) 
students can match the potential that exists in themselves with the current world of work information. Besides that, there are still other factors that influence students 'career planning. shows that many aspects affect students' career choices, including aspects of culture itself, the social context of the family and society.

\section{Conclusion}

Based on the results and the discussion mentioned before, it can be concluded several Malay cultural influences on student career planning, namely :

Discipline; melalyu classified cultural student discipline students who are disciplined to follow the activities of teaching, discipline in completing tasks, discipline in the discussion, the discipline to develop a career after finishing high school. Responsible; Malay culture students classified as students who are responsible for completing the tasks of teachers, responsible for the desired career plan. Helpful; Malay culture students have a light hand gesture in helping others, and work on things that could support student learning. Desire Learning High; Malay culture students have a high desire to learn. Diligent; Serawai culture students have properties that are diligent in helping others, and completing tasks career development.

\section{References}

Aminnurrohim, A. W., Saraswati, S., \& Kurniawan, K. 2014. Survei Faktorfaktor Penghambat Perencanaan Karier. Indonesian Journal Guidance and Counseling: Theory and Application. Vol. 3, No.2.

Correll, S. J. 2002. Gender and the Career Choice Process: The Role of Biased Self-Assessments, American Journal of Sociology, 106, 691-730.

Duane, B., \& Associates. 2002. Career Choices and Development. Jossey-Bass business \& Management Series. Germeijs, V., \& Verschueren, K. (2006). High school students' career decision-making process: Development and validation of the study of one choice task inventory.Journal of Career Assessment,14, 449-471.doi:10.1177/1069072706286510.

Heer, E. L., Cramer, S. H., \& Niles, S. G. 2004. Career Guidance and Counseling Trough the Life Span:

Sistematic approaches. Boston: Allyn and Bacon.

Luzzo, D., \& Mc Whirter, E. 2010. Sex and ethnic differences in the perception of educational and carrer-related barriers and levels of coping efficacy. Journal of Counseling and Development, 79, 61-67. 
Sharf, R.S. 2010. Applying Career Development Theory to Counseling. Edition 5 TH Pacific Grove, California. University of Delaware: Brooks/Cole Cengage Learning.

Sugiyono. 2012. Metode Penelitian Kombinasi: Mixed Methods. Bandung: Alfabeta.

Sugiyono. 2018. Metode Penelitian Kualitatif dan R\&D. Bandung. Alfabeta.

Sulusyawati, H., \& Juwanto. 2018. Potret Budaya melayu dalam Perencanaan Karier Siswa di SMA Negeri 9 Kota Bengkulu. Jurnal Psikodidaktika. Vol. 3., No., 2, pp. (1-49)

Sulusyawati, H., Hardianti, Susi. (2017) Perencanaan Karier Siswa dalam mengahadapi Masyarakat Ekonomi Asean (MEA).

Sulusyawati, H., Yusuf, A. M., \& Daharnis. (2017) Perencanaan Karier Siswa Di SMA Ditinjau dari Status Sosial Ekonomi, Jenis Kelamin, dan Jurusan. Jurnal Bikotetik. Vol. 01, No.01, pp.(0-36).

Watson, M. B., Stead, G. B., \& De Jager, A. C. 2005. The Career Development of Black and White South African University Students. Interbational Journal for the Advancement of Counseling 18, 39-47 
246 | Islamic Counseling: Jurnal Bimbingan dan Konseling Islam, Vol. 4, No. 2, 2020 